\title{
Challenges to the Implementation of Lesson Study in the Amazon
}

\author{
Mauro Marinho da Silva ${ }^{1} \quad$ Nilton Hitotuzi ${ }^{*}$ \\ 1.Federal Institute of Pará, Av. Mal. Castelo Branco, 621, Interventória, Santarém-PA, 68020-570, Brazil, \\ https://orcid.org/0000-0002-7065-9383 \\ 2.Institute of Education Sciences, Federal University of Western Pará, Av. Marechal Rondon, s/n, Caranazal, \\ 68040-070, Santarém-PA, Brazil, https://orcid.org/0000-0003-4456-5903
}

\begin{abstract}
The Japanese methodology, known in the West as Lesson Study, has been exploited in teacher education programs in various parts of the world, including the Brazilian Amazon where two pioneering studies have been carried out recently. This paper is a reflection on potential challenges to the implementation of this methodology in the Amazon. An inference that is drawn from it is that the current circumstances of the teaching culture and other cultural characteristics obtaining in this region only admit the implementation of a vague version of the Japanese Lesson Study.
\end{abstract}

Keywords: Lesson Study, Teacher education, Amazon, Research.

DOI: $10.7176 /$ RHSS/10-22-04

Publication date: November $30^{\text {th }} 2020$

\section{Introduction}

Lesson Study is a widely disseminated methodology used to help teachers to improve their teaching practice through the systematic observation of certain lessons, treating them as an object of study. Ultimately, teachers doing Lesson Study seek to understand their students' learning process and provide them with effective means to master the contents that they are taught (Stigler \& Hiebert, 1999; Lewis, 2000; Weeks \& Stepanek, 2001; Fernandez \& Chokshi, 2002; Lewis, 2002; Byrum, Jarrell, \& Munoz, 2002; Cerbin \& Kopp, 2006; Isoda, 2006; Stigler \& Hiebert, 2009; Laskowski, 2011; Lewis, 2014; Lewis, Perry, Friedkin, \& Roth, 2012, Hiebert \& Morris, 2012; Ebaeguin \& Stephens, 2015; Wake, Swan, \& Foster, 2016; Widjaja, Groves, \& Doig, 2017). In Japan, where it originated as Jugyou Kenkyuu and has been part of the teaching culture for over a hundred years (Stigler \& Hiebert, 1999), there are some cultural characteristics crucial to understanding the success of this methodology.

Based on the dimensions of national culture of Hofstede (Hofstede, 1980; G. Hofstede, G. J. Hofstede, \& Minkov, 2010), Ebaeguin and Stephens (2015) have identified five key factors of the Japanese culture that seem to have contributed to the successful implementation of Lesson Study in Japanese schools. The first is the Japanese hierarchical flexibility, which allows both experienced and novice teachers the possibility to exercise leadership roles in different Lesson Study cycles. The second consists of the equitable appreciation of collective and individual opinions of members of lesson study groups, which favors decision-making in their group discussion meetings. The third factor is the fact that the Japanese society is among the most uncertainty-avoiding societies in the world, and for this reason they strive for the establishment of strict rules for the prevention of possible risks. Not surprisingly, this culture of strict-rule enforcement is also prevalent in the Japanese Lesson Study, in which the planning is done meticulously over a prolonged period of time, and each small detail is analyzed prior to any decision that may contribute to the success of the lesson. The fourth factor concerns the high degree of masculinity of the Japanese society, whose dominant values are achievement and success, which suggests the preference for competitiveness. In the process of experiencing Lesson Study in Japanese teaching, this preference is reflected in the promotion of the desire for self-improvement. The last cultural factor considered decisive for the success of this methodology in its birthplace is the fact that Japan is one of the countries most oriented toward the establishment of long-term goals (Ebaeguin \& Stephens, 2015; Hofstede, 1980; G. Hofstede, et al., 2010), an aspect considered important when doing Lesson Study (Lewis, 2002; Murata, Lewis, \& Perry,2004; Cerbin \& Kopp, 2006; Isoda, 2006).

Lesson Study is conducted in cycles of actions. Typically, a complete Lesson Study cycle involves six steps, namely: (1) defining objectives; (2) planning the research lesson - a lesson that the group of teachers involved in the Lesson Study process uses as a laboratory to test the planned solutions aimed at solving problems of teaching and learning in the classroom; (3) teaching and observing the research lesson and data collecting; (4) reflecting on the collected data; (5) revising and teaching the lesson again - if necessary; and (6) sharing results (Lewis \& Hurd, 2011; Stepanek, Appel, Leong, Mangan, \& Mitchell, 2007). As can be inferred from the description of these steps, Lesson Study involves collaborative work, perception, reflection, high level of commitment to education and the ability to share experiences. In Japan, the experience of going thought a Lesson Study cycle implies a careful study of students, live observations of a small number of research lessons, and painstaking lesson planning and implementation aiming to optimize the achievement of learning objectives (Lewis, 2002; Murata et al., 2004; Cerbin \& Kopp, 2006; Isoda, 2006). In the literature, the success in achieving research lesson objectives is found 
in several reports of Lesson Study experiments (Fernandez \& Chokshi, 2002; Fernandez, Cannon, \& Chokshi, 2003; Murata et al., 2004; Zilliox \& Fernandez, 2004; Cerbin \& Kopp, 2006; Isoda, 2006; Roback, Chance, Legler, \& Moore, 2006; Tall, \& Isoda, 2007; Kratzer \& Teplin, 2007; Bergenske, 2008; Suh \& Fulginiti, 2012; Adams, 2013; Tatang \& Kuno, 2013; Hj Suhaili \& Shahrill, 2015; Ngang; Sam, 2015; Elliott, 2016; Griffiths, 2016; Bae, Hayes, Seitz, O'Connor, \& DiStefano, 2016; C. Lewis, 2016; J. M. Lewis, 2016; Triyanto, 2015; Chenault, 2017 ; Macedo \& Bellemain, 2017; Mynott, 2017; Widjaja et al., 2017; Nishimura, Kobayashi, \& Ohta, 2018; Schipper, Goei, de Vries, \& van Veen, 2018). These favorable reports tend to strengthen the belief in the formative potential of the methodology. Presuming this showcase of support for Lesson Study is justified, an obvious question to ask is whether its formative potential can be explored satisfactorily in cultural contexts that are eminently different from the one where the methodology originated, as is the case in the Brazilian Amazon 1.

\section{Diversity and adversity in the Amazon}

The Amazon is quintessentially more than just the combination of geo-political and economic factors (Loureiro, 2015). It includes a large diversity of flora, fauna, peoples and cultures. The question of the challenges to the implementation of Lesson Study in this region draws on a reflection on the configuration and status of its educational system vis-à-vis economic and ethnic social factors mentioned in several publications. A review of some of these texts has provided a glimpse into the type of school education that is carried out in this region, and its status in comparison with that which occurs in other regions of Brazil.

Vieira (2019), for example, draws attention to educational inequalities in Brazil, emphasizing that the precariousness of school infrastructure in the Amazon is not paralleled in other parts of this country. It is not surprising, then, that the quality of education of the Amazonian people is negatively affected, as is evidenced by the lowest scores in national standardized exams obtained by Amazonian students - this fact alone appears to require a differentiated attention to the education system of this region (Oliveira, 2016). There appears to be a pernicious influence of the economic system of the country on the performance of Amazonian students that may explain their low achievements as compared to those of students from other regions. One evidence of this is the fact that the Amazon is not favored with the material conditions that facilitate access to educational opportunities in the other regions of the country. It would be naïve, then, to subscribe to the possibility of an egalitarian educational development in a region in such a state of disadvantage, especially in this technological world, which creates an increasing dependency on its products to run entire sectors of society, including the judiciary, healthcare and educational systems, even more so now amid the COVID-19 pandemic. The access, operation and maintenance of these products require purchasing power, something that most of the Amazonian population lacks, and this constitutes a major impediment to the region's continuous flow of development.

Reflecting on the peculiarities of the Amazon, Corrêa (2018) calls attention to the need to contemplate population diversity when implementing educational programs in this region. The Amazon is home to indigenous, riverine and quilombola 2 communities, each of which having idiosyncratic identities that have to be seriously considered in their schooling process. Such ethnic diversity inevitably demands some reflection on the need to expand the skills and competences that teachers must have to work in this region. It is by no means a simple task to teach different ethnic groups with particular behaviors and learning rhythms, especially the Amazonians, who historically have faced many adversities, such as the quilombolas' struggle for freedom, the riverine communities' subjection to still precarious infrastructure conditions, or the indigenous peoples' attempt to maintain their traditions and defend their land.

Drawing a parallel between diversities in the Amazon region and their potential negative effects on the schooling process of its inhabitants, Nascimento, Cordeiro, Tavares, \& Beltrao (2018, p. 2) conceive high school education in the state of Pará as a "complex reality" because this state, although vast and rich in biodiversity and other natural resources, is the home to the students with the lowest school achievement scores in Brazil - Pará

1 The term Amazon may be confusing since it can mean different things: (a) Continental Amazon (also referred to as Pan-Amazon or International Amazon) is a region that includes parts of Brazil and parts of neighboring countries (Garcia, 2011; Mattos Neto, 2012; Loureiro, 2015); (b) Classical Amazon (also referred to as Brazilian Classical Amazon and Geographical Amazon) is composed by the seven northern states of Brazil, namely Acre, Amapá, Amazonas, Pará, Rondônia, Roraima and Tocantins (Lobão \& Silva, 2018; Loureiro, 2015); (c) Legal Amazon, or Brazilian Amazon includes the seven northern states of the Geographical Amazon plus the state of Mato Grosso and parts of the state of Maranhão. The Brazilian Amazon is subdivided into two parts: Occidental Amazon, comprising the states of Acre, Amazonas, Rondônia and Roraima; and Oriental Amazon, encompassing the states of Amapá, Mato Grosso, Pará, Tocantins and parts of Maranhão (Instituto Brasileiro de Geografia e Estatística, 2014). Therefore, when the term Amazon is used in this paper, it refers to both the Legal and the Classical Amazon.

2 A community composed of Afro-descendants who used to live in quilombos - places in the forest where runaway slaves took refuge from their white colonial masters in Brazil 
occupied the last position in the 2019 IDEB1 for high school, achieving only 3.4 points, along with the state of Amapá, according to INEP (Brazil, 2020b). Additionally, the authors argue that, in comparison to other regions, the expansion of primary education in Pará has not yet been able to overcome the high educational inequalities in urban and rural populations, considering aspects of gender and ethnicity. The precariousness of teaching is still a reality in the state, the grade-age distortion, poor infrastructure conditions and the lack of policies to guarantee the permanence and success of the student are factors that evince the educational disadvantage of the student population in Pará, which weighs unfavorably when the educational system of the Brazilian Amazon is considered as a whole.

An evident paradox obtains in the Amazon: at the same time that it thrives in diversity, natural resources and constitutes an important source of raw materials to other parts of the country and the world, the region is home to a poor population resultant from the miscegenation among riverines, quilombolas, indigenous peoples and settlers from other parts of Brazil (Sousa, Santos, \& Sousa, 2016; Fernandes, 2018). Colares and Souza (2015) consider this racial melting pot a cultural mosaic that should be taken into account by the school system and those responsible for teacher education because, when addressing Amazonian issues to Amazonian students, it is imperative that teachers have robust historical and theoretical knowledge to assume ethical, political and committed stances toward the social transformation of these students. This perspective is consistent with the reflections of Fernandes (2018), who argues for the participation of members of the beneficiary communities in the planning and implementation of provisions of social policies. For this participation to be effectively beneficial to local communities, the Amazonians will need teachers with the qualifications advocated by Colares and Souza (2015).

The misstep in the area of education in the Amazon in relation to other regions in Brazil also seems to be due to many years of Amazonian youth higher education deprivation (Daniel-Júnior, 2018), a factor that has contributed to the escalation of the adversities faced by its population. Whether riverines, indigenous peoples, quilombolas or any other ethnic groups living either in rural or urban areas, all are challenged to bear the social burden of the region's lagging economic and educational systems in addition to the failure of public authorities to provide the means for the Amazon to catch up with more developed regions of the country. This burden seems to be heavier in the inner Amazon, away from the main cities of the region. Corroborating this hypothesis, Vasconcelos (2016) reports how PARFOR2 students are characterized by their teachers: people of simple life who usually live and teach primary school students in rural and urban areas of Amazonian municipalities, and who are faced with numerous obstacles in their attempt to have access to the education offered by this program, and in their work in schools. The author argues that the own opinion of these PARFOR students about themselves is so selfdeprecating that they define themselves as being nobody, worthless or losers as a result of being instilled with the notion that the program is a deception. All these factors lend credence to the argument that high-quality schooling in the Amazon is a luxury that only a small percentage of the population can afford - private education is also an option that wealthy families normally choose for their children in other regions of the country (Cardoso \& Negrão, 2006).

The diversity and ethos landscapes of the Amazon region are also discussed by Setton (2015). This author underscores the need to understand how the actors responsible for the collapse of the educational system in this region relate to one another. She also points out attitudes of some urban Amazonian youngsters that can provide enlightening insight into this relationship, including their indifference to the problem of deforestation unquestionably a matter of global relevance - and their support for the installation of a multinational company and the illegal trade in timber. Apart from revealing the ineffectiveness of the educational system to sensitize these Amazonian youngsters to questions of vital importance for the survival of humankind, such attitudes also expose some of the effects of economic rationality and the disregard for nature that is impregnated in their minds and actions.

The brief reflections on the vast landscape of peculiarities of the Amazon presented here reveal some of the problems that place the Amazon in disadvantage with other regions, and they should be taken into consideration by researchers planning to conduct or currently conducting studies in this region. In potential comparative studies with other regions of the country, knowledge of the ethos, values and worldviews of the Amazonian peoples, as well as the economic status of the region can help them avoid producing misrepresentations of it, and may encourage them to respect it for what it is. Therefore, it is not enough to reiterate that this region needs to be treated with caution and attention, especially around education. Having said that, however, one can still argue that,

IIn 2007, the Anísio Teixeira National Institute of Educational Studies and Research (under the Brazilian Ministry of Education), commonly known as INEP, created the Índice de Desenvolvimento da Educação Básica (IDEB) as a metric to measure the progress in primary and secondary education offered in all the states of the federation. On a scale from zero to ten, IDEB combines the results of two sets of categories (a) students' achievement rates, and their remaining in or dropping out of the school system, and (b) students' results on standardized tests taken while attending primary and secondary school (Brasil, 2020a) .

2The National Plan for Primary and Secondary School Teacher Education (PARFOR) was launched in 2009 by the Brazilian Ministry of Education as an emergency program aimed at qualifying in-service teachers at undergraduate level throughout the country. Most of the teachers joining this program, however, are those working in schools across the Amazon region (Silva Grandson \& Torres, 2017). 
considering the current Amazonian context, the cultures of teaching and learning in the region may not be congenial to implementing innovative methodologies, such as the Japanese Lesson Study. It is not a matter of making negative prognoses about educational experiments in the Amazon, but of instigating reflections on the impact that these socio-economic-cultural biases may have on a region that has historically been at a rampant disadvantage in comparison with other regions of Brazil.

\section{Studies on Lesson Study in the Amazon}

To date, there are two studies on the implementation of Lesson Study in the Amazon, both designed as qualitative case studies (Yin, 2018): one centered on initial teacher education and the other, on teacher continuing professional development. In the first study, informed by authors such as Dudley (2015), Schön (2000, 2016), Zeichner (2008), Freire (1989, 1991, 2011a, 2011b, 2014), Perrenoud (2002), Fullan and Hargreaves (2012), Wenger (1998) and Shulman (1986,1987), K. L. S. J. Oliveira (2018) examines potential contributions of Lesson Study to the education of a group of aspiring EFL 1 teachers while doing their practice teaching in a government-funded secondary school. In the second study, capitalizing on Nóvoa (1999, 2007, 2009), Shulman (1986), Lewis et al. (2012), Cerbin and Kopp (2011), Stepanek et al. (2007) and Lave and Wenger (1991), H. N. Oliveira (2018) reflects on the first experience of a group of primary and secondary school EFL teachers with Lesson Study trying to understand both their attitudes toward the methodology and its effects on them.

Yet a third piece of research about Lesson Study was carried out in the Amazon, but it consisted of an interpretative analysis of K. L. S. J. Oliveira's (2018) and H. N. Oliveira's (2018) master's theses. The results of the investigation led the author to two conclusions: (i) despite recognizing the effectiveness of Lesson Study, the participants of the studies reported in both theses had only a superficial experience of the principles of the methodology; and (ii) the teaching culture to which they were exposed in their classroom experiences either as school students, undergraduates or teachers affected negatively their first experience with Lesson Study (Silva, 2020). Guided by Applied Thematic Analysis (Guest, MacQueen, \& Namey, 2012), Silva (2020) reached conclusions (i) and (ii) through discursive categories, abstracted from the theses that he analyzed, and the transcriptions of the interviews that he conducted with the two researchers.

As evidence of support for conclusion (i), Silva (2020) argues that, although the participants of both studies have demonstrated through interviews some knowledge about the concepts, objectives and functions of Lesson Study - which could give the impression of a harmonic, appropriate and successful implementation of the methodology - they were unable to put into practice most of what they had learned about the methodology. In practical terms, in both experiments there were instances of resistance to planning, individualistic attitudes, change of focus on student learning process to teacher performance, lack of interest in group discussion, and allegations of lack of time for engagement in some of the activities. The author believes that the researchers themselves have at times demonstrated superficiality in their experiences of the methodology. By way of example, Silva (2020) points out that the two researchers may have underutilized the role of knowledgeable other 2 , possibly due to their overconfidence in the participants' ability to go through a Lesson Study cycle professionally. They delegated research activities to the participants without adopting a strict follow-up protocol to make sure that the activities would be satisfactorily completed. If Silva's (2020) interpretation is correct, it becomes evident that the appropriation of theoretical knowledge demonstrated by the researchers in the preparatory sessions for the participants of their studies did not afford them complete success in their own experience of the methodology.

Expectations of successful experiments based only on understanding what a Lesson Study cycle is, its purpose, and how it works are likely to result in frustration for those involved in the process. This perspective is shared by Stigler and Hiebert (2009), who conceive of teacher learning as a cultural activity subject to maintaining forces of stabilized traditional teaching practices. Breaking with these practices can occur through teachers' awareness that their professional development is necessarily tied to the study of teaching in their natural laboratory - the schools where they work. At this point, the discussion about Silva's (2020) conclusion (ii) is already underway, because the inference that can be made is that the alienation and paralysis caused by forces supporting these traditional practices have had a negative impact on the results of these two pioneering studies with Lesson Study in the Amazon. These forces may have prevented the Lesson Study experience from being significant to the participants of both studies. The sense of significance felt by teachers doing Lesson Study is a necessary factor for the optimal exploitation of the professional development potential of this methodology (Byrum et al., 2002).

The evidence that supports Silva's (2020) conclusion (ii) includes a suspicious attitude of the class

1 English as a Foreign Language

2 The knowledgeable other, or the outside specialist (Lewis \& Hurd, 2011), an educator invited to participate in a cycle of Lesson Study, plays three key roles, according to Takahashi (2014). The first is to provide access to a deeper understanding of the content, curriculum, ideas behind the textbook and pedagogical ideas. The second is to suggest possible directions for the team to develop the research theme of the school and research lessons, in addition to trying to share observations of lessons that can help the team find solutions to problems identified during observations. Finally, the third role is to provide teachers with the opportunity to reflect on important points learned from the discussions and on what else they could learn if they were to revise and improve the lessons. 
investigated by K. L. S. J. Oliveira (2018), and the individualistic behavior of most participants reported in both studies. Silva (2020) interprets the apprehensiveness of the students as a reflection of the culture of isolation existing in the region and in other parts of the country. This seems to show that not only Brazilian teachers, but also the students are not accustomed to collaborative teaching/learning practice. On the other hand, individualism is pointed out by Felício and Silva (2017) as one of the obstacles to the valorization of the educational context as a formative space of equal importance for students and teachers participating in initial or continuing teacher education programs. The individualistic attitude of both teachers and students identified in both studies reveals the strong cultural impact caused by a methodology such as Lesson Study, whose essence consists of reflexivity and collaborative practice, when implemented in environments where individualistic ethos and worldviews prevail in the educational system.

Another evidence presented by Silva (2020) to support conclusion (ii) is the fact that the meticulously planned Lesson Study preparatory workshops, the reading assignments and the discussion sessions promoted by the researchers were not enough to prevent the emergence of cultural traits among the participants conflicting with the ethos of successful Lesson Study experiences. Behaviors observed by the researchers such as inconstancy, lack of assiduity, complacency, indifference, or negligence on the part of both the undergraduates and the teachers participating in the studies severely impaired the implementation of the methodology. An example of these instances is detailed in the study conducted by K. L. S. J Oliveira (2018). While one of the four participants of the study sought collaborative work and discussion, the others remained indifferent to his suggestions, which caused him to renounce trying to have them on board to exploit these fundamental principles of the methodology. On the other hand, in the study conducted by H. N. Oliveira, the attempt to exercise leadership by one of the participating teachers seems to have caused some complacency among the other teachers, a fact that the author believes to be justified by the work overload of these teachers, which was not a problem faced by the participant who appeared to be more engaged in the activities since he was only doing deskwork in his school during the period that he was participating in the study. This means that he had more time to focus on the tasks related to the Lesson Study experience.

It is possible, then, that in the Amazon and in other parts of the world teachers will have to settle for a modified version of the Japanese Lesson Study because some cultural environments in the societies to which they belong may be hostile to Jugyou Kenkyuu. The problem with modifications to the structure of a methodology is that they can be so drastic as to completely mischaracterize it, making the new version a travesty of the methodology in its original form. On the other hand, it is necessary to remember that one cannot attribute the success of Lesson Study only to cultural factors, but - as Ebaeguin and Stephens (2015) point out - to the existence of highly qualified teachers, to a clear expectation that teaching is a continuing commitment of the school for the sake of which the school board exercises significant responsibility, to flexible financial resources that provide teachers with time to develop professionally outside of their regular classroom activities, and to a financially beneficial teaching career that rewards innovation and leadership and retains talented teachers in the classroom.

Ebaeguin and Stephens (2015) argue that a faithful approach to the Japanese model tends to begin implementing Lesson Study cycles by asking about the skills and knowledge teachers need to be successful. In contrast, an implementation that is sensitive to the local culture seeks first and foremost to identify the habits and preexisting values that teachers have which can halt or support it. The authors also point out that not considering the possible cultural barriers when introducing Lesson Study in a new context can lead to a delay in obtaining its benefits or to a complete waste of time and effort.

\section{Conclusion}

Lesson Study, a centennial Japanese methodology used in the process of teacher professional development in various parts of the world, has recently been introduced in the Amazon through two studies that ultimately sought to understand its influences on pre- and in-service EFL teachers. But it seems that the cultural characteristics of this region, especially in the field of education, constitute a significant impediment to an optimized exploration of the methodology's formative potential. This leads to the hypothesis that under the current circumstances only a vague version of the Japanese Lesson Study would be feasible in the Amazon. Notwithstanding, as more studies are carried out with Lesson Study in this region, the implementation of cycles of this methodology preserving its fundamental characteristics is not an implausible reality.

\section{References}

Adams, J. W. (2013). A case study: using Lesson Study to understand factors that affect teaching creative and critical thinking in the elementary classroom. (Doctoral dissertation, Drexel University). Available at: https://core.ac.uk/download/pdf/190336061.pdf (Accessed: October 14, 2020).

Bae, C. L., Hayes, K. N., Seitz, J., O'Connor, D., \& DiStefano, R. (2016). A coding tool for examining the substance of teacher professional learning and change with example cases from middle school science lesson study. Teaching and teacher education, 60, 164-178. Available at: https://doi.org/10.1016/j.tate.2016.08.016 
(Accessed: October 15, 2020).

Brasil (2020a). IDEB - resultados e metas. Instituto Nacional de Estudos e Pesquisas Educacionais Anísio Teixeira. Available at: http://ideb.inep.gov.br/resultado/resultado/resultado.seam?cid=1355794 (Accessed: October 15, 2020).

Brasil (2020b) INEP - IDEB: Índice de Desenvolvimento da Educação Básica. Available at: http://portal.inep.gov.br/ideb (Accessed: October 18, 2020).

Byrum, J. L., Jarrell, R., \& Munoz, M. (2002). The perceptions of teachers and administrators on the impact of the Lesson Study initiative. US Department of Education, 1-27. Available at: http://citeseerx.ist.psu.edu/viewdoc/download?doi=10.1.1.924.7658\&rep=rep1\&type=pdf $\quad$ (Accessed: October 14, 2020).

Cardoso, A. C. D., \& Negrão, M. R. G. (2006). Considerações sobre a pobreza no Brasil e suas manifestações nas cidades da Amazônia. Novos Cadernos NAEA,9(1), 95-118. Available at: https://periodicos.ufpa.br/index.php/ncn/article/view/59 (Accessed: October 23, 2020).

Cerbin, W.; Kopp, B. (2006). Lesson Study as a model for building pedagogical knowledge and improving teaching. International Journal of Teaching and Learning in Higher Education, 18(3), 250-257. Available at: https://eric.ed.gov/?id=EJ1068058 (Accessed: October 14, 2020).

Chenault, K. (2017). Building collaborative pedagogy: Lesson Study in higher education. College Quarterly, 20(1), 1-23. Available at: https://files.eric.ed.gov/fulltext/EJ1131159.pdf (Accessed: October 14, 2020).

Colares, A. A., Souza, R. (2015) Educação e diversidade: interfaces e desafios na escola de tempo integral. HISTEDBR ON-Line, 66, 247-266. Available at: https://periodicos.sbu.unicamp.br/ojs/index.php/histedbr/article/view/8643713 (Accessed: October 14, 2020).

Corrêa, E. S. (2018). A Política de Formação de Professores de Língua Inglesa e os Desafios da Prática Cotidiana na Escola Pública. (Doctoral dissertation, Universidade Federal do Amazonas). Available at: https://tede.ufam.edu.br/handle/tede/6442 (Accessed: October 14, 2020).

Daniel-Júnior, G. M. (2018). Análise do processo de interiorização do ensino superior público na região amazônica. (Doctoral dissertation, Universidade Federal do Amazonas). Available at: https://tede.ufam.edu.br/bitstream/tede/6759/5/Tese_GeraldoMagela_PPGSCA (Accessed: October 14, 2020).

Dudley, P. (Ed.). (2015). Lesson Study: Professional learning for our time. London: Routledge.

Ebaeguin, M., \& Stephens, M. (2015). Teacher professional development through Lesson Study: adaptation or cultural transition. In 7th ICMI-East Asia regional conference on mathematics education. Cebu City, Philippines, 373-378. Available at:

https://www.researchgate.net/profile/Marlon_Ebaeguin/publication/276411848_Teacher_professional_developm ent_through_Lesson_Study_Adaptation_or_cultural_transition/links/5562 be $1508 \mathrm{ae} 6 \mathrm{f} 4 \mathrm{dcc} 95314 \overline{\mathrm{f}} / \mathrm{Teacher}$ professional-development-through-Lesson-Study-Adaptation-or-cultural-transition.pdf (Accessed: October $15,2020)$.

Elliott, J. (2016). Significant themes in developing the theory and practice of lesson study. International Journal for Lesson and Learning Studies, 5(4), 274-280. Available at: https://doi.org/10.1108/IJLLS-08-2016-0022 (Accessed: October 14, 2020).

Felício, H. M. S., \& Silva, C. M. R. (2017). Currículo e formação de professores: uma visão integrada da construção do conhecimento profissional. Diálogo Educacional, 17(51), 147-166. Available at: http://dx.doi.org/10.7213/1981-416x.17.051.ao01 (Accessed: October 14, 2020).

Fernandes, J. S. N. (2018). Políticas de desenvolvimento na Amazônia: um olhar para as famílias ribeirinhas. Anais do XVI Encontro Nacional de Pesquisadores em Serviço Social, 16(1), 1-14. Available at: https://www.periodicos.ufes.br/abepss/article/view/22138 (Accessed: October 14, 2020).

Fernandez, C., Cannon, J., \& Chokshi, S. (2003). A US-Japan Lesson Study collaboration reveals critical lenses for examining practice. Teaching and Teacher Education,19(2), 171-185. Available at: https://doi.org/10.1016/S0742-051X(02)00102-6 (Accessed: October 14, 2020).

Fernandez, C.; Chokshi, S. (2002). A practical guide to translating Lesson Study for a U.S. setting. Phi Delta Kappan, 84(2), 128-134. Available at: https://journals.sagepub.com/doi/pdf/10.1177/003172170208400208?casa_token=h_W3zCUdI7kAAAAA: zD35zvrI9AA7sMmS6nw3CjWaJnwFLPi0VCYLm_15AW_1P2wE6AGr3bT1XzYg9Tt8bL-4quFL8yso6w (Accessed: October 14, 2020).

Freire, P. (1989). Educação como prática de liberdade. São Paulo: Paz e Terra.

Freire, P. (1991). A educação na cidade. São Paulo: Cortez.

Freire, P. (2011a). Pedagogia da autonomia: saberes necessários à prática docente. São Paulo: Paz e Terra.

Freire, P. (2011b). Educação e mudança (34th ed.). São Paulo: Paz e Terra.

Freire, P. (2014). Pedagogia da Esperança: um reencontro com a pedagogia do oprimido. São Paulo: Paz e Terra. Fullan, M., \& Hargreaves, A. (2012). Professional capital: Transforming teaching in every school. New York: 
Teachers College Press.

Garcia, B. (2011). The Amazon from an international law perspective. Cambridge: Cambridge University Press.

Griffiths, J. (2016). Bridging the school placement gap with peer micro-teaching Lesson Study. International Journal for Lesson and Learning Studies, 5(3), 227-238. Available at: https://doi.org/10.1108/IJLLS-112015-0035 (Accessed: October 14, 2020).

Guest, G., MacQueen, K. M., \& Namey, E. E. (2012). Applied Thematic Analysis. Thousand Oaks: SAGE Publications, Inc.

Hiebert, J., \& Morris, A. K. (2012). Teaching rather than teachers, as a path toward improving classroom instruction. Journal of Teacher Education, 63(2), 92-102. Available at: https://doi.org/10.1177/0022487111428328 (Accessed: October 15, 2020).

Hj Suhaili, A., \& Shahrill, M. (2015). A comparison study of Bruneian primary mathematics teachers' perceived learning in Lesson Study. In 7th ICMI-East Asia regional conference on mathematics education. Cebu City, Philippines. Available https://www.researchgate.net/profile/Masitah_Shahrill/publication/281852301_A_Comparison_Study_of_B runeian_Primary_Mathematics_Teachers\%27_Perceived_Learning_in_Lesson_Study/links/55fb775b08ae0 7629e0 $\overline{7}$ bce1/A-Comparison-Study-of-Bruneian-Primary-Mathematics-Teachers-Perceived-Learning-inLesson-Study.pdf (Accessed: October 15, 2020).

Hofstede, G. (1980). Culture's consequences: International differences in work-related values. Beverly Hills: SAGE Publications, Inc.

Hofstede, G., Hofstede, G. J., \& Minkov, M. (2010). Cultures and organizations: Software of the mind (3rd ed.). New York: McGraw-Hill.

Instituto Brasileiro de Geografia e Estatística. (2014). Amazônia Legal. Available at: https://www.ibge.gov.br/geociencias/organizacao-do-territorio/estrutura-territorial/15819-amazonialegal.html?edicao $=16194 \& t=$ sobre (Accessed: October 19, 2020).

Isoda, M. (2006). Nesting features of developing teachers' perspectives: A Lesson Study project for prospective teachers in mathematics with history and technology. In APEC International Symposium on Innovation and Good Practice for Teaching and Learning Mathematics through Lesson Study, Khon Kaen Thailand on, 16, 35-48. Available at: https://home.kku.ac.th/crme/APEC/PDF2006/file5Masami\%20Isoda.pdf (Accessed: October 15, 2020).

Kratzer, C. C., \& Teplin, A. S. (2007). From Lesson Study to Lesson Link [R]: Classroom-Based Professional Development. Online submission. Available at: https://files.eric.ed.gov/fulltext/ED502890.pdf (Accessed: October 15, 2020)

Laskowski, T. (2011). Jugyokenkyu (Lesson Study) in America. Kumamoto Journal of Culture and Humanities, 102, 59-77. Available at: https://ci.nii.ac.jp/naid/110008425931/ (Accessed: October 15, 2020).

Lave, J., \& Wenger, E. (1991). Situated learning: legitimate peripheral participation. Cambridge: Cambridge University Press.

Lewis, C. (2000). Lesson study: The core of Japanese professional development. Invited address to the Special Interest Group on Research in Mathematics Education, Annual meeting of the American Educational Research Association (AERA), New Orleans. Available at: http:/files.eric.ed.gov/fulltext/ED444972.pdf (Accessed: October 15, 2020).

Lewis, C. (2002). Does Lesson Study have a future in the United States? Nagoya Journal of Education and Human Development, 1, 1-23. Available at: https://eric.ed.gov/?id=ED472163 (Accessed: October 15, 2020).

Lewis, C. (2014). How Do Japanese Teachers Improve their Instruction? Synergies of Lesson Study at the School, District and National Levels. Board on Science Education Commissioned Paper, 1-21. Available at: https://sites.nationalacademies.org/cs/groups/dbassesite/documents/webpage/dbasse_084385.pdf (Accessed: October 15, 2020).

Lewis, C. (2016). How does lesson study improve mathematics instruction?. ZDM, 48(4), 571-580. Available at: https://doi.org/10.1007/s11858-016-0792-x (Accessed: October 15, 2020).

Lewis, C. C., Perry, R. R., Friedkin, S., \& Roth, J. R. (2012). Improving teaching does improve teachers: Evidence from lesson study. Journal of teacher education, 63(5), 368-375. Available at: https://doi.org/10.1177/0022487112446633 (Accessed: October 15, 2020).

Lewis, C. C., \& Hurd, J. (2011). Lesson study step by step: How teacher learning communities improve instruction. New Hampshire: Heinemann.

Lewis, J. M. (2016). Learning to lead, leading to learn: How facilitators learn to lead lesson study. $Z D M, 48(4)$, 527-540. Available at: https://doi.org/10.1007/s11858-015-0753-9 (Accessed: October 15, 2020).

Lobão, M. S. P., \& Silva, R. G. (2018). Spillovers espaciais no desenvolvimento educacional dos municípios da Amazônia Clássica Brasileira. REDES - Revista do Desenvolvimento Regional, 23(2), 290-315. Available at: https://dialnet.unirioja.es/ejemplar/496827 (Accessed: October 19, 2020).

Loureiro, V. R. (2015). Amazônia: temas fundamentais sobre o meio ambiente (1st ed.). Belém: Cultural Brasil. 
Macedo, A. D. R., \& Bellemain, P. M. B. (2017). Desenvolvimento profissional do professor de matemática a partir da Jugyou Kenkyuu no ensino de grandezas e medidas. In J. A. M. Melo (Org.). Anais do VI Seminário Nacional de Histórias e Investigações delem Aulas de Matemática, Campinas - SP. Available at: https://www.cempem.fe.unicamp.br/pf-cempem/aluska_dias_ramos_de_macedo_paula moreira baltar bellemain.pdf (Accessed: Octōber, $\overline{15} 2020$ ).

Mattos Neto, A. J. (2012). Indicação geográfica: instrumento de proteção jurídica dos produtos agroambientais das populações tradicionais amazônicas no estado democrático de direito. In A. J. Mattos Neto, H. Lamarão Neto, \& R. R. Santana (Orgs.), Direitos humanos e democracia inclusiva (p. 29-46). São Paulo: Saraiva.

Murata, A., Lewis, C., \& Perry, R. (2004). Teacher learning in lesson study: Developing professional capacity and resources. North American Chapter of the International Group for the Psychology of Mathematics Education October 2004 Toronto, Ontario, Canada, $985 . \quad$ Available at: http://citeseerx.ist.psu.edu/viewdoc/download?doi=10.1.1.690.2023\&rep=rep1\&type=pdf\#page=34 (Accessed: October 15, 2020).

Mynott, J. P. (2017). A Primary Head Teacher's Exploration of Lesson Study. (Doctoral dissertation, University of Hertfordshire). Available at: http://uhra.herts.ac.uk/handle/2299/18330 (Accessed: October 14, 2020).

Nascimento, A. W. S., Cordeiro, Y, E, M., Tavares, F. B., \& Beltrao, N. E. S. (2018). Educação e sociedade: o papel das políticas de ensino médio na formação de estudantes em escola pública da Amazônia paraense. Interações, 19(2), 417-428. Available at: https://doi.org/10.20435/inter.v19i2.1668 (Accessed: October 15, 2020).

Ngang, T. K., \& Sam, L. C. (2015). Principal support in lesson study. Procedia-Social and Behavioral Sciences, 205, 134-139. Available at: https://doi.org/10.1016/j.sbspro.2015.09.040 (Accessed: October 15, 2020).

Nishimura, K., Kobayashi, R., \& Ohta, S. (2018). Lesson Study at upper secondary level in Japan: potential and issues. Educational Designer, 3(11), Available $1-15 . \quad$ at: http://www.educationaldesigner.org/ed/volume3/issue11/article44/ (Accessed: October 15, 2020).

Nóvoa, A. (1999). Profissão professor (2nd ed.). Porto: Porto.

Nóvoa, A. (2007). Desafios do trabalho dos professores no mundo contemporâneo. São Paulo: SINPRO.

Nóvoa, A. (2009). Para uma formação de professores construída dentro da profissão.

Revista de Educación, 350, 203-218. Available at: http://www.educacionyfp.gob.es/revista-deeducacion/numeros-revista-educacion/numeros-anteriores/2009/re350/re350-09.html (Accessed: October 15, 2020).

Nóvoa, A. (2017). Firmar a posição como professor, afirmar a profissão docente. Cadernos de Pesquisa, 47(166), 1106-1133. Available at: https://doi.org/10.1590/198053144843 (Accessed: October 15, 2020).

Oliveira, H. N. (2018). Lesson Study: uma experiência com três professores de inglês da rede pública estadual de Santarém-PA. (Master's thesis, Universidade Federal do Oeste do Pará). Available at: https://sucupira.capes.gov.br/sucupira/public/consultas/coleta/trabalho Conclusao/viewTrabalhoConclusao.jsf?popup=true\&id_trabalho=7061491 (Accessed: October 15, 2020).

Oliveira, K. L. S. J. (2018). Lesson Study na formação inicial de professores: uma experiência com licenciandos de Letras/Inglês da Universidade Federal do Oeste do Pará. (Master's thesis, Universidade Federal do Oeste do Pará). Available at: http://www.ufopa.edu.br/ppge/images/dissertacoes/turma_2016/Ktia_Lais.pdf (Accessed: October 15, 2020).

Oliveira, L. A. (2016). A construção da identidade do docente que atende ao aluno com deficiência intelectual incluido na classe comum da escola regular no interior da Amazônia paraense. (Doctoral dissertation, Universidade Estadual de Campinas). Available at: http://repositorio.unicamp.br/handle/REPOSIP/319224 (Accessed: October 15, 2020).

Perrenoud, P. (2002). A prática reflexiva no oficio de professor: profissionalização e razão pedagógica. Porto Alegre: Artmed.

Roback, P., Chance, B., Legler, J., \& Moore, T. (2006). Applying Japanese lesson study principles to an upperlevel undergraduate statistics course. Journal of Statistics Education, 14(2), 1-20. Available at: https://doi.org/10.1080/10691898.2006.11910580 (Accessed: October 15, 2020).

Schipper, T., Goei, S. L., de Vries, S., \& van Veen, K. (2018). Developing teachers' self-efficacy and adaptive teaching behaviour through lesson study. International Journal of Educational Research, 88, 109-120. Available at: https://doi.org/10.1016/j.ijer.2018.01.011 (Accessed: October 15, 2020).

Schön, D. A. (2000). Educando o profissional reflexivo: um novo design para o ensino e a aprendizagem (R. C. Costa, Trans.). Porto Alegre: Artmed.

Schön, D. A. (2016). The reflective practitioner: How professionals think in action. New York: Routledge.

Setton, M. G. J. (2015). Juventude na Amazônia: experiências e instituições formadoras. Curitiba: CRV.

Shulman, L. S. (1986). Those who understand: Knowledge growth in teaching. Educational researcher, 15(2), 414. Available 
https://journals.sagepub.com/doi/pdf/10.3102/0013189x015002004?casa token=WttVAlFCKD0AAAAA:e KK2ObW64TIzlX1ue1KOBtCY45HFRUJoT8AEcGeg1nqSdaI0uHQrDB6M3rzcUFwE1FDj1K6Y-7np (Accessed: October 15, 2020).

Shulman, L. (1987). Knowledge and teaching: Foundations of the new reform. Harvard educational review, 57(1), 1-23. Available at: https://doi.org/10.17763/haer.57.1.j463w79r56455411 (Accessed: October 15, 2020).

Silva, M. M. (2020). Análise interpretativa de percepções sobre o uso da Lesson Study na formação inicial e contínua de professores de inglês na Amazônia. (Unpublished master's thesis). Universidade Federal do Oeste do Pará, Santarém, PA.

Silva Neto, N. da C. e, \& Torres, J. C. (2018). O PARFOR no contexto da política nacional de formação de profissionais do magistério da educação básica. Colloquium Humanarum, 14(3), 111-122. Available at: http://journal.unoeste.br/index.php/ch/article/view/2133 (Accessed: October 15, 2020).

Sousa, L. C. R., Santos, R. B. N., \& Sousa, D. S. P. (2016). Pobreza multidimensional na Amazônia legal: uma análise sobre o Índice de Desenvolvimento da Família (IDF). Desenvolvimento Regional em debate: $D R d, 6(3)$, 125-148. Available at: https://dialnet.unirioja.es/servlet/articulo?codigo=5733094 (Accessed: October 15, 2020).

Stepanek, J., Appel, G., Leong, M., Mangan, M. T., \& Mitchell, M. (2007). Leading Lesson Study: a practical guide for teacher and facilitators. Thousand Oaks: Corwin Press.

Stigler, J. W., \& Hiebert, J. (1999). The teaching gap: best ideas from the world's teachers for improving education in the classroom. New York: The Free Press.

Stigler, J. W., \& Hiebert, J. (2009). Closing the teaching gap. Phi Delta Kappan, 91(3), 32-37. Available at: https://doi.org/10.1177/003172170909100307 (Accessed: October 15, 2020).

Suh, J. M., \& Fulginiti, K. (2012). Situating the learning” of teaching: Implementing lesson study at a professional development school. School-University Partnerships, 5(2), 24-37. Available at: https://pdfs.semanticscholar.org/334b/6cd3fbf16eb543cab000fdc2119ef23ada42.pdf Accessed: October 15, 2020).

Takahashi, A. (2014). The Role of the Knowledgeable Other in Lesson Study: Examining the Final Comments of Experienced Lesson Study Practitioners. Mathematics Teacher Education and Development, 16(1), 1-16. Available at: https://eric.ed.gov/?id=EJ1046714 (Accessed: October 15, 2020).

Tall, D., \& Isoda, M. (2007). Long-term development of mathematical thinking and lesson study. Prepared as a Chapter for a Forthcoming Bookon Lesson Study, 1-34. Available at: http://homepages.warwick.ac.uk/staff/David.Tall/pdfs/dot2007x-tall-isoda-lessonstudy.pdf (Accessed: October 15, 2020).

Tatang, S., \& Kuno, H. (2013). Lesson Study Development in Asian Countries:-Focusing on "School Improvement Program" in an Indonesian Primary School一. Available at: https://core.ac.uk/download/pdf/147577152.pdf (Accessed: October 15, 2020).

Triyanto, T. (2015). Building collaborative learning through lesson study. In International Conference on Teacher Training and Education. Sebelas Maret University. Available at: https://www.neliti.com/publications/169388/building-collaborative-learning-through-lesson-study\#cite (Accessed: October 15, 2020).

Vasconcelos, E. R. (2016). A formação de professores na Amazônia e as dimensões socioambientais: um estudo sobre o PARFOR. (Doctoral dissertation, Universidade Federal de Santa Catarina). Available at: https://repositorio.ufsc.br/handle/123456789/168212 (Accessed: October 15, 2020).

Vieira, E. B. (2019). Qualidade e equidade da educação e crescimento econômico na Amazônia brasileira. (Doctoral dissertation, Universidade Federal de Uberlândia). Available at: http://repositorio.ufu.br/handle/123456789/25156 (Accessed: October 15, 2020).

Wake, G., Swan, M., \& Foster, C. (2016). Professional learning through the collaborative design of problemsolving lessons. Journal of Mathematics Teacher Education, 19(2-3), 243-260. Available at: https://doi.org/10.1007/s10857-015-9332-9 (Accessed: October 15, 2020).

Weeks, D. J., \& Stepanek, J. (2001). Lesson Study: Teachers Learning Together. Northwest Teacher, 2(2), 1-25. Available at: https://eric.ed.gov/?id=ED469880 (Accessed: October 15, 2020).

Wenger, E. (1998). Communities of practice: Learning, meaning, and identity. Cambridge: Cambridge University Press.

Widjaja, W., Vale, C., Groves, S., \& Doig, B. (2017). Teachers' professional growth through engagement with lesson study. Journal of Mathematics Teacher Education, 20(4), 357-383. Available at: https://doi.org/10.1007/s10857-015-9341-8 (Accessed: October 15, 2020).

Yin, R. K. (2018). Case Study Research and Applications: Design and methods (6th ed.). Los Angeles: SAGE Publications, Inc.

Zeichner, K. (2008). Zeichner, K. M. (2008). Uma análise crítica sobre a" reflexão" como conceito estruturante na formação docente. Educação \& Sociedade, 29(103), 535-554. Available at: https://doi.org/10.1590/S0101- 
73302008000200012 (Accessed: October 15, 2020).

Zilliox, J., \& Fernandez, M. (2004). Lesson Study in preservice education. North American Chapter of the International Group for the Psychology of Mathematics Education. October 2004. Toronto, Ontario, Canada, 1237. Available at: http://citeseerx.ist.psu.edu/viewdoc/download?doi=10.1.1.690.2023\&rep=rep1\&type=pdf\#page=286 (Accessed: October 15, 2020). 